\title{
The Positive Impact of Auditory Intellectually Repetition Learning Model Assisted by Domino Card on Mathematics Learning Outcomes
}

\author{
Ni Putu Adiani ${ }^{1}$, Maria Goreti Rini Kristiantari ${ }^{2}$ \\ ${ }^{12}$ Program Studi Pendidikan Guru Sekolah Dasar, Fakultas Ilmu Pendidikan, Universitas Pendidikan Ganesha, Bali, Indonesia
}

\author{
A R T I C LEINFO \\ Article history: \\ Received 2 Juni 2020 \\ Received in revised form \\ 12 Juli 2020 \\ Accepted 10 Agustus 2020 \\ Available online 28 Agustus \\ 2020 \\ kata kunci: \\ auditory intellectually \\ repetition, hasil belajar \\ matematika, kartu domino \\ keywords: \\ auditory intellectually \\ repetition, mathematics \\ learning outcomes, domino \\ card
}

\begin{abstract}
A B S T R A K
Penelitian ini didasari oleh permasalahan pada hasil belajar siswa yang masih rendah karena siswa masih sulit dalam memahami rumus dalam matematika dan mengangap matematika sebagai pembelajaran yang sulit. Penelitian ini bertujuan untuk mengetahui pengaruh model pembelajaran Auditory Intellectually Repetition berbantuan kartu domino terhadap hasil belajar matematika siswa kelas IV SD. Rancangan penelitian yang digunakan adalah non equivalen control group design. Populasinya sebanyak 9 kelompok yang berjumlah 338 siswa. Pengambilan sampel menggunakan teknik cluster random sampling dimana kelompok eksperimen berjumlah 35 siswa dan kelompok kontrol berjumlah 40 siswa. Tes objektif dalam bentuk pilihan ganda digunakan sebagai instrumen pengumpulan data. Data yang diperoleh merupakan data hasil belajar matematika pada ranah kognitif dan dianalisis menggunakan uji-t dengan rumus polled varians, hasil analisis yang didapatkan adalah thitung $=3,818>$ tabel $=1,666$, dengan data yang diperoleh maka bisa dikatakan bahwa model pembelajaran Auditory Intellectually Repetition berbantuan kartu domino memberikan pengaruh terhadap hasil belajar matematika siswa. Sehingga dengan diberlukannya model ini bisa mempermudah cara belajar siswa dalam memahami rumus matematika.
\end{abstract}

\section{A B S T R A C T}

This research-based on problems in students learning outcomes is still low because students are still difficult in understanding mathematics formulas and consider mathematics as difficult learning. This research aimed to know the effect of the Auditory Intellectually Repetition learning model assisted by domino card results on student mathematics learning outcomes grade IV Research design used a nonequivalent control group. The population was 9 groups which amounts to 338 students. Sampling used cluster random sampling technique when chosen experimental group total of 35 students and control group total of 40 students. Objective test type multiple choice used as data collection instruments. Data obtained was data on learning outcomes in mathematics in the cognitive realm and analyzed used uji-t by formula polled variance, analysis result obtained was tcount=3,818 > ttable $=1,666$, this showed Auditory Intellectually Repetition learning model-assisted domino card give effect to student mathematics learning outcomes. So with the enactment of this model can simplify the way students learn in understanding mathematic formulas.

\section{Introduction}

Education is the main thing that affects the quality of human resources in Indonesia. Education will encourage changes in human life to better things. In line with (Sutrisno, 2016), education is an important element that directs students to have good intelligence, attitudes, and personalities. The world of education, especially in formal education, is related to curriculum, according to (Lazwardi, 2017) curriculum is a plan which contains the implementation of learning so that educational goals can be achieved. The existence of a curriculum in formal education level is expected to affect the output at each level of education. Curriculum is the most important part of education and is designed to achieve educational goals (Fujiawati, 2016).

Various lessons are designed in the elementary school levelcurriculum, one of that is mathematics learning. Mathematics is closely related to everyday life to solve some problems and become a reference for other branches of science. In line with (Rahmah, 2018), mathematics refers to logical thinking and becomes a reference for other sciences. According to (Siagian, 2017), mathematics is a science that uses reasoning and accurate with number symbols. In mathematics 
learning, there is also a need for a learning process to transfer mathematical knowledge, learning process designed by teacher to teach students. According to (Sunhaji, 2014), learning process is defined as an effort made so that a change occurs when affects student learning outcomes. Learning outcomes are very important for teachers to find out how successful in teaching. According to (Susanto, 2013), learning outcomes are a process experienced by students from learning activities that involve cognitive, affective, and psychomotor domains. Meanwhile, according to (Fitrianingtyas \& Radia, 2017), learning outcomes is a measure used to determine how far students understand the material. (Sulastri et al., 2015) stated that learning outcomes are a repeated stage in the formation of a person. So, learning outcomes are a process wherein there is a change in individual learners where these changes occur in the affective, cognitive, and psychomotor domains of students after learning activities. Learning outcomes examined in this study are the results of learning mathematics in cognitive domain. According to Bloom in (Susanto, 2013), cognitive realm is the mastery of students to absorb, understand, and accept the learning given. It can be said that this cognitive domain is the result of learning that emphasizes student's knowledge in understanding material.

Good and optimal learning outcomes is certainly much influenced by teacher's role, students and learning tools support the learning process. Teacher must be able to make situation more meaningful and enjoyable. Students easily understand mathematics learning material, this will be able to produce optimal learning outcomes. The use of appropriate and varied learning tools can help students understand mathematics easier. However, in reality, the results of students' learning mathematics, especially in cognitive domain, have not achieved optimal results. Learning mathematics becomes a difficult lesson and as a feared lesson at the fourth grade level of elementary school, these problems affected learning outcomes, especially in cognitive aspects. Students are less understand how to solve it and apply formulas to find answers to questions given by teacher. The essence of learning mathematics is to better understand and deepen knowledge of mathematical formulas and must be able to apply formulas appropriately to certain problems, this is of course very much related to the ability to think / process reasoning from students themselves besides that also guidance or explanation from teachers are needed during learning process so that students understand material easily. Problems like this also occur in Sudirman General Cluster of South Denpasar in fourth grade of elementary school where from students midterm test result at the time of making observations, from 338 students as many as 253 students score is still less than KKM, this means $75 \%$ of students need to get attention because only $25 \%$ of students scored able to achieve or exceed predetermined KKM. It was also strengthened by interviews with fourth-grade homeroom teachers who stated that there were still many students who received mathematics scores below KKM, because students thought learning mathematics was too difficult, understanding of formulas was also lacking and when the teacher explained many students did not pay attention because they thought mathematics learning was less attractive. With a problem like this, an innovative learning model is needed as a solution to this problem, because it is in line with the opinion (Trianto, 2010) that learning model will further encourage student activity and it is necessary to know that the selection of a learning model must be adjusted to material taught to learners. The learning model must be designed in such a way as to allow students to quickly understand material provided and of course create a conducive atmosphere for learning. One learning model that is considered suitable for learning mathematics is Auditory Intellectually Repetition Learning Model assisted by domino cards.

The Auditory Intellectually Repetition learning model emphasizes three things, Auditory, Intellectually (thinking process), Repetition (repetition at the end of learning.), This is in line with (Sakti \& Hikayati, 2017) states that Auditory Intellectually Repetition learning model will produce effective learning because this learning model will build students' thinking processes, students are also explained by the teacher so that here students do not only find their answers but are also guided by the teacher and get repetition at the end of learning and this will greatly impact the learning results from students themselves. In addition, (Astuti et al., 2018) argue that the Auditory Intellectually Repetition learning model is an exercise in ability to reason, argue, solve problems and deepen understanding of students by giving repetition. (Mustika \& Kinanti, 2018) state that this learning model can produce effective learning because in this model it teaches that learning starts from listening/listening, connecting something meaningful such as theory with things that are done, and repetition that can help students remember a material longer. So, it can be said that this learning model will help learning process to be more effective and emphasize more on student understanding under the teacher guidance and repetition at the end of the lesson will help students remember material that has been given by the teacher. Auditory Intellectually Repetition learning model 
certainly has advantages in line with (Ariska et al., 2016) this learning model has several advantages which train senses of hearing and courage of students in expressing opinions, train students in problem-solving, train students to deepen their memory by given repetitions and make students more active. In addition, according to (Shoimin, 2014), students are more active in expressing their ideas, the knowledge and skills that students have will be more utilized in learning, with their abilities students can express their opinions, this will be very useful for students with low abilities, students have inner motivation to give opinions and students gain experience to find solutions to problems.

The use of Auditory Intellectually Repetition learning model will be assisted by domino cards so that mathematics learning is not too feared so that learning atmosphere is more enjoyable. The domino card used is not an ordinary domino card but a math domino card. This math domino card contains questions and answers and students will play them. One set of domino cards will be given to each group. With existence of this domino card, it hoped that learning mathematics to be fun learning will no longer be learning that is feared by students, because students can learn and play. This is in line with (Pajar, 2019), a math domino card is a tool or media that is made almost the same as a domino card in general where questions are packaged in the form of domino cards, students must match the questions with the answers on the card correctly, this will make students more comfortable in answering questions. Furthermore, according to (Abqari et al., 2018) this domino math card is a method used that can attract students' interest in learning because it will focus more on students. After all, students themselves will find answers through domino card. This domino card has advantages, in line with (Muryaningsih \& Irianto, 2015) domino cards can develop the skills of students in solving the questions on the card. (Akbar, 2018) stated that the advantage of using this card, it will make the atmosphere more pleasant and foster critical thinking from students. It is different according to (Nurfitriyanti \& Lestari, 2016), math domino cards have the advantage of being an intermediary used in training students in critical thinking where this will be able to make students find playing strategies whose final goal is to win.

Based on this explanation, it can be concluded that the Auditory Intellectually Repetition learning model assisted with domino cards makes students understand mathematics learning material accompanied by guidance from the teacher of the course and with the help of domino cards students are more comfortable and happier in learning mathematics so that students do not feel afraid or bored when learning takes place. The implementation of this model can affect student learning outcomes, especially in the cognitive domain. Based on the explanation that has been described, a research entitled "The Influence of Auditory Intellectually Repetition Learning Model Aided by Domino Cards on Mathematics Learning Outcomes of Fourth Grade Elementary School in Gugus Jendral Sudirman, South Denpasar, Academic Year 2019/2020" was carried out. The objective to be achieved in the implementation of this research is to determine the significant effect of the Auditory Intellectually Repetition learning model assisted by Domino Cards on the Fourth Grade Mathematics Learning Outcomes of Elementary School in Gugus Jendral Sudirman South Denpasar for the $2019 / 2020$ academic year.

\section{Research Method}

This type of research is quantitative using a quasi-experimental design with a non-equivalent control group design. This design was chosen by researchers because researchers find it difficult to control variables when students are outside the environment that affects the research carried out. In the non-equivalent control group design, it involved 2 subjects, the experimental group and the control group. The pretest is given before giving a treatment, it aims to equalize the group and use the t-test analysis technique. After the new equivalence is done, the experimental group will be given treatment using Auditory Intellectually Repetition learning model assisted by domino cards and the control group using conventional learning. The final stage is that both groups are given a post-test to obtain data on the results of the two groups. There are stages of the implementation of this research which starts from the first stage, preparation where in this stage the researcher conducts interviews with the principal who is in the General Sudirman Gugus Denpasar Selatan to find out whether there are superior classes in the cluster, determine the learning material, consult the pretest and posttest, RPP preparation, sample determination, provision of posttest instrument trials, validation of posttest instruments. The second stage is the implementation in this stage the researcher provides treatment to the experimental group with the Auditory Intellectually Repetition learning model assisted by domino cards while for the control group with conventional learning, posttest giving to the experimental group and the control group. The third stage is the final stage where the researcher analyzes the results of the research and conducts a hypothesis test. 
This study also has a population where according to (Sugiyono, 2012), the population is the entire subject or object which has certain personalities or traits to be studied. Meanwhile, according to (Setyosari, 2013), the population is an object as a whole consisting of individuals and events of special concern. The population used by the researcher was the fourth-grade elementary school of Elementary School in Gugus Jendral Sudirman for the 2019/2020 school year, where there were 5 primary schools with a total population of 338 fourth grade elementary school students. The fourth grade Elementary School in Sudirman General Cluster, South Denpasar, 2019/2020 school year, there are no superior classes, all are equally based on interviews that have been conducted with the respective Principals.

After the population is determined, it is followed by sample determination where according to (Sugiyono, 2012), the sample is a small part of the population which has certain unique characteristics. Meanwhile, according to (Setyosari, 2013), samples are defined as objects that are used as examples to represent the object as a whole. According to (Agung, 2014) the sample is part of the population that is used as the subject. The sampling technique used is cluster random sampling where not individuals/individuals are randomized but the class because they cannot change the previously formed class. The lottery method cluster is selected as a means of determining the sample. Of the five public schools consisting of nine fourth grade in the Sudirman General Gugus, a draw was conducted. The first drawing was carried out to determine the two groups that were used as research samples, by writing all fourth grade Elementary School in Gugus Jendral Sudirman, then rolled up after being rolled into an empty box and then shaken then the researcher took two rolls of paper for the two groups which later will be sampled. From the first drawing, two classes were selected, class A Elementary School of 13 Sesetan and grade four B Elementary School of 6 Sesetan. After getting two classes to become samples, the next research will be given a pretest to measure the academic equivalence of students. The results or score from pretest between these two groups will be used as an equalization which will be analyzed using the t-test with the prerequisites being tested first using normality test and homogeneity test. After data obtained is normally distributed and homogeneous, then proceed with t-test with the group criteria declared equivalent at the $5 \%$ significance level with $\mathrm{dk}=\mathrm{n} 1+\mathrm{n} 2-2$ on the criteria if the price of $\mathrm{t}$ count $\leq t$ table then $\mathrm{H} 0$ is accepted so that the group is equal. After getting an equal result, the second draw is carried out. Based on the second drawing, the experimental group and the control group were selected, with details in Table 1 as follows.

Table 1. Sample

\begin{tabular}{cccc}
\hline Elementary school name & Group & Class & Total \\
\hline $\begin{array}{c}\text { Elementary School of 13 } \\
\text { Sesetan }\end{array}$ & Experiment & IV A & 35 \\
\hline Elementary School of 6 Sesetan & Control & IV B & 40 \\
\hline & Total & & 75 \\
\hline
\end{tabular}

In this study, the analyzed data on mathematics learning outcomes in the cognitive domain of fourth grade Elementary School in Gugus Jendral Sudirman in the 2019/2020 academic year. The data collection method used is the test method, according to (Agung, 2014) the test method is data obtained through giving assignments in the form of tests that must be done. The test given is related to mathematics learning at the fourth-grade elementary school level. The data collection instrument used was an objective test in the form of ordinary multiple-choice (PGB). Before the test is given to students, the instrument testing must first be held. The test that is planned as a testing instrument is 40 test items. Of these 40 questions will be tested first, data from the test results will be tested for the instrument.

First is the validity test: the validity test is a test to test the accuracy of using a measuring instrument, in this test, there are two types of testing, the content validity and the test item validity. In terms of content validity, the compilation of questions is required according to the applicable curriculum and learning materials at the time of research, based on basic competencies, indicators and of course assessed by experts who are experts in their fields (judges), while item validity is a validity test with biserial point correlation. The results of the test item validity test got 30 valid questions out of 40 questions that had been tested. After the validity test is carried out, it is continued with a different power test, which according to (Arikunto, 2015), distinguishing power is an ability possessed by the questions used to be able to distinguish between clever and less intelligent students. 
This test is done by dividing the upper group with the lower group, first taking the top $50 \%$ as the top group and the bottom $50 \%$ as the bottom group of the total sample, which is tested for differentiation is only valid test items which get 2 very good criteria. , both 16 and 12 test items. Next is the level of difficulty, where what is meant is the question is said to be good if the question is not too easy and not too difficult in solving the problem. The difficulty index is denoted by the letter P which stands for the proportion of the item difficulty index. For the analysis of the level of difficulty of the test kits, it was found that the results of the test kits were in the medium category, where for easy criteria were 6 , medium 19 , and 5 test items were difficult. The last is the reliability test, according to (Arikunto, 2015), the test can be trusted, if it provides fixed results. Reliability test can only be tested for valid questions. In the r11 test reliability coefficient, benchmarks are generally used (Sudijono, 2015). (1) if $\mathrm{r} 11>0.70$ means that the test that has been tested is declared reliable, (2) if r11<0.70 means that the competency test that has been tested is declared unreliable. Based on the results of the calculation of the reliability test of the students' cognitive mathematics learning results obtained $\mathrm{r} 11$ of 2.05 . This indicates that the test that has been tested is suitable for use as an instrument with high-reliability criteria. The grid of the data collection instruments is presented in Table 02 as follows.

Table 2. Data Collection Instruments

\begin{tabular}{|c|c|c|c|c|c|c|c|}
\hline \multirow{2}{*}{$\begin{array}{c}\text { Basic } \\
\text { competencies }\end{array}$} & \multirow[b]{2}{*}{ Indicator } & \multicolumn{4}{|c|}{ Cognitive level } & \multirow[b]{2}{*}{$\begin{array}{l}\text { question } \\
\text { number }\end{array}$} & \multirow{2}{*}{$\begin{array}{c}\text { number } \\
\text { of } \\
\text { questions }\end{array}$} \\
\hline & & C1 & C2 & C3 & C4 & & \\
\hline \multirow[t]{11}{*}{$\begin{array}{l}\text { 3.9. Describe and } \\
\text { determine } \\
\text { perimeter and } \\
\text { of area } \\
\text { rectangles, squares, } \\
\text { triangles. }\end{array}$} & $\begin{array}{l}\text { 3.9.1 Explain the meaning } \\
\text { of squares, rectangles and } \\
\text { triangles. }\end{array}$ & $\sqrt{ }$ & & & & 1 and 2 & 2 \\
\hline & $\begin{array}{l}\text { 3.9.2 Classifying the } \\
\text { properties of shapes } \\
\text { (square, rectangle, triangle) }\end{array}$ & & $\sqrt{ }$ & & & $\begin{array}{l}3,4 \text { and } \\
5\end{array}$ & 3 \\
\hline & $\begin{array}{l}\text { 3.9.3 Apply the perimeter } \\
\text { formula. }\end{array}$ & & & $\sqrt{ }$ & & $\begin{array}{c}6,7,8 \\
\text { and } 30\end{array}$ & 4 \\
\hline & $\begin{array}{l}\text { 3.9.4 Apply the formula for } \\
\text { area of a square. }\end{array}$ & & & $\sqrt{ }$ & & 9 and 10 & 2 \\
\hline & $\begin{array}{l}\text { 3.9.5 Apply the formula for } \\
\text { the perimeter of a rectangle }\end{array}$ & & & $\sqrt{ }$ & & $\begin{array}{l}11,12 \\
\text { and } 13\end{array}$ & 3 \\
\hline & $\begin{array}{l}\text { 3.9.6 Apply the area } \\
\text { formula for a rectangle. }\end{array}$ & & & $\sqrt{ }$ & & $\begin{array}{l}14,15 \\
\text { and } 16\end{array}$ & 3 \\
\hline & $\begin{array}{l}\text { 3.9.7 Apply the formula for } \\
\text { the perimeter of a triangle. }\end{array}$ & & & $\sqrt{ }$ & & $\begin{array}{l}17 \text { and } \\
18\end{array}$ & 2 \\
\hline & $\begin{array}{l}\text { 3.9.8 Apply the formula for } \\
\text { the area of a triangle. }\end{array}$ & & & $\sqrt{ }$ & & $\begin{array}{l}19 \text { and } \\
20\end{array}$ & 2 \\
\hline & $\begin{array}{l}\text { 3.9.9 Determine the area of } \\
\text { the compound shape } \\
\text { (square, rectangle and } \\
\text { triangle). }\end{array}$ & & & & $\sqrt{ }$ & $\begin{array}{l}21 \text { and } \\
22\end{array}$ & 2 \\
\hline & $\begin{array}{l}3.9 .10 \text { Determine the } \\
\text { circumference of a flat } \\
\text { shape related to everyday } \\
\text { life. }\end{array}$ & & & & $\sqrt{ }$ & $\begin{array}{l}23,24 \\
25,26 \\
\text { and } 36\end{array}$ & 5 \\
\hline & & & 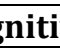 & e Le & & & number \\
\hline \multirow[t]{3}{*}{ BasicCompetencies } & Indikator & C1 & $\mathrm{C} 2$ & C3 & C4 & $\begin{array}{l}\text { question } \\
\text { number }\end{array}$ & $\begin{array}{c}\text { of } \\
\text { questions }\end{array}$ \\
\hline & $\begin{array}{l}3.9 .11 \text { To determine the } \\
\text { area of the flat shape } \\
\text { associated with daily life. }\end{array}$ & & & & $\sqrt{ }$ & $\begin{array}{l}27 \text { and } \\
28\end{array}$ & 2 \\
\hline & Total & & & & & & 30 \\
\hline
\end{tabular}

The data analysis method used is inferential statistical method. According to (Agung, 2014), the inferential statistical method is a method of processing data by applying inferential statistical 
formulas in hypothesis testing where later conclusions can be drawn through the results of the tests carried out. The first test is the normality test, the data distribution normality test uses the Kolmogorov-Smirnov test to determine whether the data is normally distributed / not. The test criteria is if the maximum score is $\mid$ FT - FS $\mid \leq$ Kolmogorov-Smirnov table, then the data is normally distributed. Otherwise if the maximum score is $\mid$ FT - FS $\mid>$ Kolmogorov-Smirnov table, then the data is not normally distributed. The formula can be seen in Table 3 as follows.

Table 3. Kolmogorov-Smirnov Normality test

\begin{tabular}{|c|c|c|c|c|c|}
\hline No & $\mathbf{X i}$ & $X=\frac{X i \quad X}{S D}$ & FT & FS & $\left|F_{T}-F_{S}\right|$ \\
\hline & & & & & \\
\hline & & & & & \\
\hline & & & & & \\
\hline Dst. & & & & & \\
\hline
\end{tabular}

Information:

(Sumber : Cahyono, $2015: 19$ )

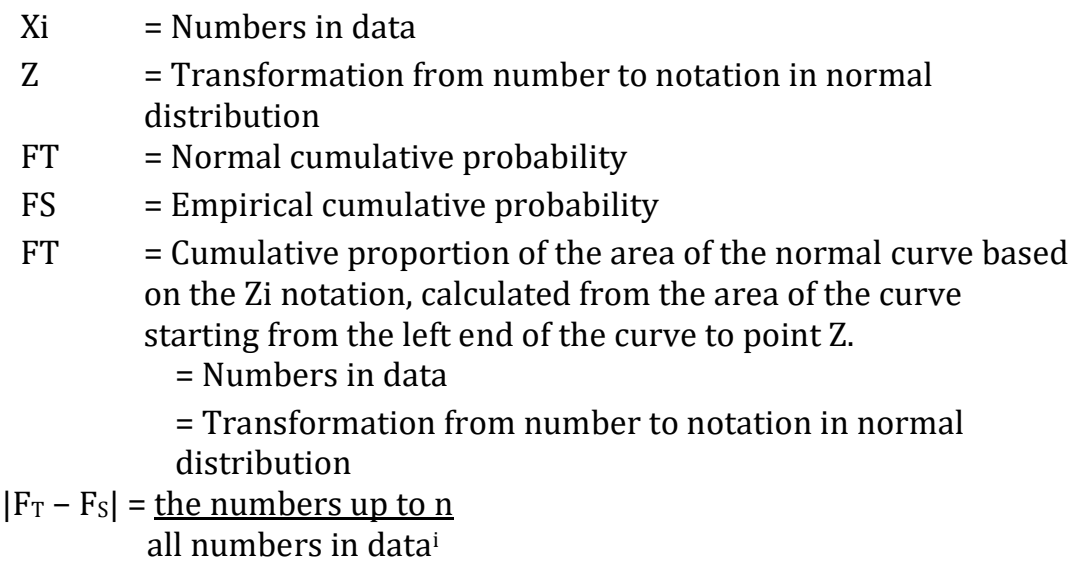

The second test is the variance homogeneity test. The homogeneity test is carried out to show that the differences that occur in the hypothesis test actually occur due to differences in variance between groups, the homogeneity test is carried out when the data is normally distributed. The homogeneity test of variance was carried out with the formula $\mathrm{F}$ test:

\section{$\mathrm{F}=\underline{\text { Varian terbesar }}$ \\ Varian terkecil}

(Sugiyono, $2017: 140$ )

The last is hypothesis testing, hypothesis testing can be done after carrying out the normality test and homogeneity test. The hypothesis tested is: H0: there is no significant difference in mathematics learning outcomes between the groups that are taught using auditory intellectually repetition (AIR) learning model assisted by domino cards and groups that are taught with conventional learning in fourth grade students of Elementary School in Gugus Jendral Sudirman, South Denpasar. 2019/2020 teaching.

\section{Result and Discussion}

The result of the Auditory Intellectually Repetition learning model assisted by domino cards applied to experimental group and conventional learning in control group. Description of the data in this study, average, standard deviation and variance. The research design used was a pretest and posttest, where pretest data was only used for group equalization, while posttest data were analyzed to obtain data on of cognitive mathematics learning outcomes for fourth grade elementary school students. Posttest results in both groups can be seen in Table 4 as follows. 
Table 4. PostTest Data on Mathematics Cognitive Learning Outcomes of Fourth Grade Elementary School Students Sample Group

\begin{tabular}{ccc}
\hline Analysis Result & Experiment Group & Control Group \\
\hline $\mathrm{N}$ & 35 & 40 \\
\hline Average & 80,4 & 70,2 \\
\hline Variance & 98,48 & 96,44 \\
\hline Standard Deviation & 9,92 & 9,82 \\
\hline Minimum Score & 63 & 57 \\
\hline Maximum Score & 100 & 90 \\
\hline PAP Category & Baik & Cukup \\
\hline
\end{tabular}

The data tested using t-test which previously had to meet prerequisite tests, normality test of data distribution and the homogeneity test. The data distribution normality test used the Kolmogorov-Smirnov test with experimental group got maximum score of $\mid$ FT - FS $\mid=0.09$ and the Kolmogorov-Smirnov table score for a significance level of $5 \%(\alpha=0.05)=0.224$ because the maximum score | FT - FS | <Kolmogorov-Smirnov table, the data obtained is normally distributed. Meanwhile, control group got maximum score of $\mid$ FT - FS $\mid=0.07$ and the Kolmogorov-Smirnov table score for a significance level of $5 \%(\alpha=0.05)=0.210$ because maximum score $\mid$ FT - FS | $<$ Kolmogorov-Smirnov table, data is normally distributed. The details can be seen in Table 5 as follows.

Table 5. Results of Post-test Data Normality Test for Experiment and Control Groups

\begin{tabular}{cccc}
\hline Control Group & $\begin{array}{c}\text { Maximum Score } \mid \text { Ft } \\
- \text { Fs } \mid\end{array}$ & $\begin{array}{c}\text { Nilai Tabel Kolmogorov- } \\
\text { Smirnov }\end{array}$ & Keterangan \\
\hline $\begin{array}{c}\text { IV B Elementary } \\
\text { School of 13 Sesetan }\end{array}$ & 0,09 & 0,224 & Normal distributed \\
\hline $\begin{array}{c}\text { IV B Elementary } \\
\text { School of 6 Sesetan }\end{array}$ & 0,07 & 0,210 & Normal distributed \\
\hline
\end{tabular}

Furthermore, homogeneity test was carried out using F-test with result of Fcount $=1.02$. Whereas for $5 \%$ significance level $(\alpha=0.05)$, numerator degrees of freedom $(n 1-1)=(35-1)=34$ and denominator degrees of freedom $(\mathrm{n} 2-1)=(40-1)=39$, it is obtained Ftable $=1.73$. Thus, Fcount $=1.02<$ Ftable $=1.73$. This means that post-test data on learning results in the cognitive domain of mathematics for fourth grade students at Elementary School of 13 Sesetan and grade four Elementary School of 6 Sesetan have homogeneous variances, details can be seen in Table 6 below.

Table 6. Post-test Data Homogeneity Test Results

\begin{tabular}{ccccccc}
\hline Testing & $\mathbf{S}_{\mathbf{1}}{ }^{\mathbf{2}}$ & $\mathbf{S}_{\mathbf{2}}{ }^{\mathbf{2}}$ & $\mathbf{D k}$ & $\mathbf{F}_{\text {count }}$ & $\mathbf{F}_{\text {table }}$ & Conclusion \\
\hline Homogeneity Test & 98,48 & 96,44 & 73 & 1,02 & 1,73 & Homogen \\
\hline
\end{tabular}

Then proceed with t-test hypothesis test with polled variance formula. Hypothesis tested is H0: there is no significant difference in mathematics learning outcomes between group that was taught using auditory intellectually repetition (AIR) learning model assisted by domino cards and group taught with conventional learning in fourth grade students of Elementary School in Gugus Jendral Sudirman, Denpasar selatan, 2019 academic year / 2020. The results of t-test analysis can be seen in Table 7 below.

Table 7. T-test results

\begin{tabular}{cccccccc}
\hline Group & Average & $\mathbf{S}^{2}$ & $\mathbf{N}$ & $\mathbf{D k}$ & $\mathbf{t}_{\text {count }}$ & $\mathbf{t}_{\text {table }}$ & Conclusion \\
\hline Experiment & 80,4 & 98,48 & 35 & 73 & 3,818 & 1,666 & $\mathrm{H}_{0}$ rejected \\
\cline { 1 - 3 } Control & 70,2 & 96,44 & 40 & & & & \\
\hline
\end{tabular}


Based on the results of $t$-test where $t$ count $=3.818>t$ table $=1.666$ at a significance level of $5 \%(\mathrm{dk}=35+40-2=73)$, then H0 is rejected, this means that Auditory Intellectually Repetition learning model assisted by domino cards affects learning outcomes mathematics in fourth-grade students of Elementary School in Gugus Jendral Sudirman Denpasar Selatan in 2019/2020 academic year. At the beginning, pretest results have same ability between experimental group and control group, while after being given treatment in experimental group learning outcomes have a big difference with control group. The difference was due to the treatment of Auditory Intellectually Repetition learning model assisted by domino cards applied to experimental group. The average score of experimental groups was 80.4 in a good category, while for control group was 72.0 with a sufficient category that used the PAP reference (Benchmark Reference Assessment). The experimental group is in good category because it is a group that is given treatment using the Auditory Intellectually Repetition learning model assisted by domino cards, whereas it is known that this learning model is suitable in mathematics learning. After all, it emphasizes more on understanding and repetition at the end, also with the help of domino cards so that students can create a pleasant learning atmosphere so this will greatly affect student learning outcomes. While control group is a group that is not given treatment, this group is taught with conventional learning which tends to provide information from teachers and passive students so that this will lead to a lack of student understanding which will affect their learning outcomes. With this, the mean score of this group is smaller than the experimental group.

This is supported empirically by research that has been conducted by (Ajis et al., 2018) wherein his research states that Auditory Intellectually Repetition learning model assisted by mind mapping affects learning outcomes of student's colloid system. The results of his research state that Auditory Intellectually Repetition learning model assisted by mind mapping helps students solve problems and makes students have high memory and interest in learning. The similarity with this research is that both studies effect the Auditory Intellectually Repetition model. The difference lies in the aid used, the location of the study, and the dependent variable. It is also supported by research from (Sakti \& Hikayati, 2017), which states that Auditory Intellectually Repetition model affects students' mathematics learning outcomes. The results of his research, this model makes students more active in expressing their opinions. The equation lies in both having an effect on student learning outcomes and studying the same model. The difference is in the use of assistance used, in this study (Sakti \& Hikayati, 2017) did not use any assistance while in this study using domino cards. Another research that supports (Nansabaris \& Sdn, 2019) states that the Auditory Intellectually Repetition learning model affects learning outcomes with a large tcount acquisition than table (2.124> 2.067). The equation both examines the Auditory Intellectually Repetition model. The difference lies at the level of the class that is the subject, in the study by (Nansabaris \& Sdn, 2019) using the fifth grade of Elementary School, while in this study using the fourth grade of Elementary School. It is also supported by research from (Ulva \& Resti Ayu Suri, 2019), in the results of the research, it is stated that the Auditory Intellectually Repetition learning model affects students' mathematical communication skills. This study states that the average score of the experimental group is 85.66 and the control group is 77.23, this indicates a fairly large difference between the two groups. The similarity lies in both studying the Auditory Intellectually Repetition model and both have a higher mean score in the experimental group than the control group. The difference lies in the dependent variable being tested, (Ulva \& Resti Ayu Suri, 2019) is the ability of mathematical communication while in this study it is the result of learning mathematics.

Based on the four supporting research that has been described, it can be said that this research is very relevant to the research conducted, where it is concluded that the Auditory Intellectually Repetition learning model affects the dependent variable. Auditory Intellectually Repetition learning model is a learning model that emphasizes student activities related to listening, speaking, presenting, responding, solving problems. In line with the opinion (Rahayuningsih, 2017), this learning model is a model that emphasizes listening, uses reasoning, and deepens the material. There are 3 important things in the Auditory Intellectually Repetition learning model; Auditory, according to Meier (in Huda, 2013), auditory is closely related to the sense of hearing whereby using the sense of hearing we can capture the information conveyed. Intellectually, According to (Huda, 2013), intellectuality is a means used by someone in thinking activities and in conveying ideas. In this intellectual activity not only involves the brain, but several things support it, mental and emotional. Repetition, according to Slamet (Huda, 2013), repetition needs to be given to students, repetitions given can be given at a certain time or on material that is considered difficult to understand by students. 
In carrying out this research some obstacles occur, when implementing this learning model, at the beginning of the meeting the students are not maximal to take part in learning following the given learning model syntax. Another obstacle is that students do not understand how to use the math domino card that is given, they must first be directed how to use it by the teacher so that the teacher is here to guide students deeper to facilitate student understanding. At the second and third meeting students are already at the stage of understanding the syntax of the learning model and how to use math dominoes. At the fourth to sixth meeting, the students fully understood the syntax of the given learning model and the correct use of math domino cards, so that the class atmosphere was active students and mathematics learning could be done while learning and playing.

Auditory learning model Intellectually Repetition assisted by domino cards is a learning model that emphasizes auditory (listening), intellectually (ability to think), and repetition (deepening at the end of learning) where this will be assisted by the presence of domino cards. This domino card contains questions and answers where students have to match them, it is hoped that with this card students can learn while playing, so that this will greatly affect student learning outcomes, especially in the cognitive domain of mathematics learning.

\section{Conclusion}

Based on hypothesis testing using t-test analysis get $\mathrm{t}$ count $=3.818$. The price is then compared with the $t$ table price with a significance level of $5 \%(\alpha=0.05)$ and $\mathrm{dk}=35+40-2=73$ so that the $\mathrm{t}$ table price $=1.666$. Because $\mathrm{t}$ count $=3.818>\mathrm{t}$ table $=1.666$ then $\mathrm{H} 0$ is rejected, with the mean of learning outcomes in the experimental group is 80.4 and the mean of the control group is 72.0. It can be concluded that the Auditory Intellectually Repetition learning model assisted with domino cards affects the fourth-grade mathematics learning outcomes of Elementary School in Gugus Jendral Sudirman, South Denpasar, for the 2019/2020 academic year. Some suggestions that can be given are to teachers in choosing a learning model, it should be adjusted to the material to be given, the principal should be used as a benchmark in the use of suitable learning models in elementary schools, especially in mathematics learning and to other researchers to be used as a reference in conducting similar research.

\section{References}

Abqari, F. T., Irawan, E. B., \& Sa'dijah, C. (2018). Media Permainan Kartu Domino Untuk Meningkatkan Keterampilan Berhitung Konversi Pecahan Desimal Siswa Kelas IV. Jurnal Pendidikan: Teori, Penelitian, Dan Pengembangan, 3(9), 1190-1199. http://dx.doi.org/10.17977/jptpp.v3i9.11550

Agung, A. A. G. (2014). Metodelogi Penelitian Pendidikan. Malang Aditya Media Publishing.

Ajis, A., Wildan, \& Siahaan, J. (2018). Pengaruh Penerapan Model Pembelajaran Auditory Intelectually Repetitin (Air) Berbantuan Media Mind Mapping Terhadap Hasil Belajar Sistem Koloid Siswa Kelas XI MS SMA Negeri 1 Kediri. Jurnal Skripsi Pendidikan Kimia Universitas Mataram, 7. http://eprints.unram.ac.id/6844/1/JURNAL\%20SKRIPSI\%20ABDUL\%20AJIS.pdf

Akbar, K. (2018). Penggunaan Kartu Domino Matematika Dalam Framework Elpsa Untuk Meningkatkan Hasil Belajar Siswa. Media Pendidikan Matematika, 6(1), 39. https://doi.org/10.33394/mpm.v6i1.1815

Arikunto, S. (2015). Dasar-Dasar Evaluasi Pendidikan. Jakarta : Bumi Aksara.

Ariska, M., Fuaddunazmi, M., \& Habibi, H. (2016). Pengaruh Pendekatan Pembelajaran Air (Auditory Intellectually Repetition ) Dengan Metodedemonstrasi Terhadap Kemampuan Berkomunikasi Dan Kemampuan Berpikir Kritis Siswa. Lensa: Jurnal Kependidikan Fisika, 4(2), 62. https://doi.org/10.33394/j-lkf.v4i2.91

Astuti, R., Yetri, \& Anggraini, W. (2018). Pengaruh Model Pembelajaran Auditory Intellectually Repetition (AIR) Terhadap Kemampuan Berfikir Kritis Siswa Pada Materi Kemagnetan Kelas IX SMP Negeri 1 Penengahan Lampung Selatan. Indonesian Journal of Science and Mathematics Education, 01(2), 1-12. https://doi.org/10.24042/ijsme.v1i2.2765

Cahyono, T. (2015). Statistik Uji Normalitas. Purwekerto : Yayasan Sanitarian Banyumas. 
Dahlan, D. (2018). Penggunaan Media Kartu Domino Dalam Meningkatkan Keterampilan Operasi Hitung Pada Siswa Kelas III SDN 240 Harue Kabupaten Bulukumba. Publikasi Pendidikan, 8(2). https://doi.org/10.26858/publikan.v8i2.5964

Fitrianingtyas, A., \& Radia, A. H. (2017). Peningkatan hasil belajar IPA melalui model discovery learning siswa kelas iv SDN Gedanganak 02. Mitra Pendidikan, 1(6), 708-720. https://ejurnalmitrapendidikan.com/index.php/e-jmp/article/view/141/65

Fujiawati, F. S. (2016). Pemahaman Konsep Kurikulum dan Pembelajaran dengan Peta Konsep Bagi Mahasiswa Pendidikan Seni. Jurnal Pendidikan Dan Kajian Seni, 1(1), 16-28. http://dx.doi.org/10.30870/jpks.v1i1.849

Huda, Miftahul. 2013. Model-Model Pengajaran dan Pembelajaran. Yogyakarta : Pustaka Pelajar.

Lazwardi, D. (2017). Manajemen Kurikulum Sebagai Pengembangan Tujuan Pendidikan. Al-Idarah: Jurnal Kependidikan Islam. 7(1). https://doi.org/10.24042/alidarah.v7i1.1112

Muryaningsih, S., \& Irianto, S. (2015). Math Games Domino Effect on the Results of the Learning Math Fractions in Class IV SD Negeri 1 Kalikabong. Jurnal Dinamika Pendidikan Dasar, 7(2), 31-42. $10.30595 /$ dinamika.v7i2.930

Mustika, H., \& Kinanti, N. (2018). Pengaruh Penerapan Model Pembelajaran Auditory Intellectually Repetition (Air) Terhadap Kemampuan Komunikasi Matematika Siswa Di Kelas Viii Smp Negeri 1 Pasir Penyu. MES: Journal of Mathematics Education and Science, 3(2), 153-158. https://doi.org/10.30743/mes.v3i2.495

Nansabaris, S. D. N., \& Sdn, D. A. N. (2019). Pengaruh Penerapan Model Pembelajaran Auditory, Intellectually, Repetition (Air) Terhadap Hasil Belajar Matematika Siswa Kelas V SDN 07 Nansabaris dan SDN 16 Nansabaris. Jurnal: Pendidikan Matematika, 3(2), 391-396. $10.31004 /$ basicedu.v3i2.17

Nurfitriyanti, M., \& Lestari, W. (2016). Penggunaan Alat Peraga Kartu Domino Terhadap Hasil Belajar Matematika. Jkpm, 01(02), 247-256. http://dx.doi.org/10.30998/jkpm.v1i2.1192

Pajar, J. (2019). Jurnal PAJAR ( Pendidikan dan Pengajaran ). 3, 18-25. https://pajar.ejournal.unri.ac.id/index.php/PJR

Rahayuningsih, S. (2017). Penerapan Model Pembelajaran Matematika Model Auditory Intellectually Repetition (Air). Erudio Journal of Educational Innovation, 3(2), 67-83. https://doi.org/10.18551/erudio.3-2.6

Rahmah, N. (2018). Hakikat Pendidikan Matematika. Al-Khwarizmi: Jurnal Pendidikan Matematika Dan Ilmu Pengetahuan Alam, 1(2), 1-10. https://doi.org/10.24256/jpmipa.v1i2.88

Sakti, H. G., \& Hikayati, S. (2017). Pengaruh Penggunaan Model Pembelajaran Air ( Auditory , Intellectualy, Repetition) Terhadap Hasil Belajar Mata Pelajaran Matematika Pada Siswa Kelas VII SMP Negeri 2 Lembar Lombok Barat Tahun Pelajaran 2016 / 2017. Society, Jurnal Jurusan $\begin{array}{llll}\text { Pendidikan } \quad \text { IPS } & \text { Ekonomi, }\end{array}$ https://journal.uinmataram.ac.id/index.php/society/article/view/1505

Setyosari, P. (2013). Metode Penelitian Pendidikan dan Pengembangan. Jakarta : Prenadamedia Group.

Shoimin, A. (2014). 68 Model Pembelajaran Inoovatif dalam Kurikulum 2013. Yogyakarta: Ar-Ruzz Media.

Siagian, M. D. (2017). Pembelajaran Matematika Dalam Persfektif Konstruktivisme. NIZHAMIYAH: Jurnal Pendidikan Islam Dan Teknologi Pendidikan, VII(2), 61-73. http://dx.doi.org/10.30821/niz.v7i2.188

Sudijono, A. (2015). Pengantar Evaluasi Pendidikan. Jakarta : Rajawali Pers.

Sugiyono. (2012). Metode Penelitian Kuantitatif, Kualitatif dan R\&D. Bandung : Alfabeta.

Sugiyono. (2017). Statistika untuk Penelitian. Bandung : Alfabeta. 
Sulastri, Imran, \& Firmansyah, A. (2015). Meningkatkan Hasil Belajar Siswa Melalui Strategi Pembelajaran Berbasis Masalah Pada Mata Pelajaran IPS Di Kelas V SDN 2 Limbo mMakmur Kecamatan Bumi Raya. Jurnal Kreatif Tadulako Online, 3(1), 92. http://jurnal.untad.ac.id/jurnal/index.php/JKTO/article/view/4110

Sunhaji. (2014). pengertian pembelajaran. Konsep Manajemen Kelas dan Implikasinya dalam Pembelajaran. 2(2). https://doi.org/10.24090/jk.v2i2.551

Susanto, A. (2013). Teori Belajar dan Pembelajaran di Sekolah Dasar. Susanto : Prenadamedia Group.

Sutrisno. (2016). Berbagai Pendekatan dalam Pendidikan Nilai dan Pendidikan Kewarganegaraan. Jurnal Dimensi Pendidikan Dan Pembelajaran;, 5, 26-37. http://dx.doi.org/10.24269/dpp.v4i1.56.

Trianto. (2010). Model Pembelajaran Terpadu. Jakarta Bumi Aksara.

Ulva, M., \& Resti Ayu Suri, I. (2019). Pengaruh Model Pembelajaran Auditory Intellectualy Repetition Terhadap Kemampuan Komunikasi Matematis Peserta Didik. Jurnal Pendidikan Matematika, 7(1), 15-21. http://dx.doi.org/10.30738/union.v6i3.3080 